\title{
Efficacy of Different Herbicides and its Combination against the Weed Flora of Transplanted Rice: A Review
}

\author{
Shipra Yadav ${ }^{1 *}$, R. B. Yadav, Sanjay Singh Chuhan², \\ Rahul Kumar ${ }^{1}$ and Virendra Kumar ${ }^{1}$ \\ ${ }^{1}$ Department of Agronomy' Sardar Vallabhbhai Patel University of Agriculture \& Technology, \\ Meerut (UP) India \\ ${ }^{2}$ Department of Agronomy, Narendra Deva University of Agriculture \& Technology, \\ Kumarganj, Ayodhya, (UP) India \\ *Corresponding author
}

\section{A B S T R A C T}

\begin{tabular}{|l|}
\hline Key w ord s \\
Herbicides, Weed \\
Flora of \\
Transplanted Rice \\
\hline Article Info \\
\hline $\begin{array}{l}\text { Accepted: } \\
\text { 20 July 2020 } \\
\text { Available Online: } \\
10 \text { August } 2020\end{array}$ \\
\hline \hline
\end{tabular}

\begin{abstract}
Rice is an important food crop extensively grown in India. Several factors are responsible for reducing the yield of transplant rice. However, weed infestation is the major threat to productivity of transplanted rice. Normally the loss in yield ranges between $16-20 \%$, yet in severe cases the yield losses can be more than 50\%, depending upon the species and intensity of weeds. Weed flora under transplanted condition is very much diverse and consists of grasses, sedges and broad-leaved weeds causing yield reduction of rice crop up to $76 \%$. These weeds could be controlled through manual and chemical methods. Manual method is though very common but cost intensive and chemical weed control is used to overcome weeds infestation which is easy, quick, time saving, cost effective and the most reliable method to control weeds in rice. Herbicides when applied alone is although economical but may have limitation of resistance development, shift in weed flora etc. Therefore, presently there is a need to use high efficacy herbicides in combination coupled with broad spectrum nature to control the complex weed flora in transplanted rice.
\end{abstract}

\section{Introduction}

Rice is the world's most important food and more than half of the world's population depends on rice for food, calories and protein, especially in developing countries among all staple food crops More than $90 \%$ of the world rice is produced and consumed in Asia, which is a native for $60 \%$ of the earth's population. With the increasing food demand by the growing population, rice will continue to be primary source of food. Rice is primary food crop of India and therefore, national food security system largely depends on productivity of rice ecosystems. The world's total area under rice is $161.1 \mathrm{mha}$ and production is about $480.3 \mathrm{mt}$ along with the productivity of $2.98 \mathrm{t} / \mathrm{ha}$. Rice is the first most important crop in India where it is grown in an area of 44.1 mha with an annual production of $106.7 \mathrm{mt}$ and average productivity is $2.4 \mathrm{t} / \mathrm{ha}$. Rice is grown in both 
kharif and Rabi seasons under diverse ecological and climatic conditions apart from socio-economic diversities of the state. $33 \%$ of total rice land has got irrigation facilities and rest is totally dependent upon rainfall. Among various depressing factors, abiotic stress i.e. water and nutrient stress and biotic stress i.e. weed infestations in the field are the most crucial factors due to which rice production is unpredictable and considerably low. Weeds are the most important biological constraint to decrease yields wherever rice is grown. It has been estimated that without weed control, at a yield level of 7 to $8 \mathrm{t} . h a^{-1}$, yield loss can be as high as about $90 \%$ (Ferrero and Tinarelli, 2007). Various methods like cultural, mechanical, biological and chemicals are used for weed control. The chemical weed control method is becoming popular among the farmers because it is the most efficient means of reducing weeds competition with minimum labour cost (Baloch, 1994). Chemical weed management becomes a competitive and promising way to control weeds in transplanted rice, at least for first few weeks after transplanting of crop. The use of herbicides, therefore appears to be the only alternative (Alstorm, 1990) and in the present context, it is most preferable and farmer can easily go for it, because day-byday labour scarcity increased. The yield of transplanted rice in India is much lower than that of transplanted rice in other rice growing countries. Therefore, proper weed management is essential for satisfactory rice production in India. Weed free period during the critical period of competition is essential for obtaining optimum rice yield. This can be achieved by removing the weeds by mechanical, cultural or chemical means or by their combinations. Subsistence farmers in India spend more time and energy on weed control than any other aspects of rice cultivation. Chemical weed control has been gaining popularity in India in recent years. In addition, during peak period, the availability of labour is becoming a serious problem by time. So, herbicides are used successfully for weed control in rice fields for rapid effect, easier to application and lower cost involvement in comparison to the traditional methods of hand weeding (Mian and AlMamun, 1969). Both pre-emergence and Postemergence herbicides can be used in rice fields and they are effective. But weeds are the most severe constraints and timely weed management is crucial for increasing the productivity of rice. In such situation, the application of pre-emergence herbicides like Pendimethalin plays significant role in controlling weeds (Singh and Singh, 2010). Similarly, several authors reported to Azimsulfuron (Singh et al., 2009), Pyrazosulfuron, Penoxsulam (Chauhan \& Seth, 2013) and post emergence Bispyribac (Khaliq et al., 2012) herbicides which are considered to be an alternative/ supplement to hand weeding. Most of the pre-emergence herbicides viz., butachlor, pretilachlor and thiobencarb were applied in large quantities for weed management in transplanted rice. These herbicides are very effective for grasses and less effective against sedges and broadleaved weeds (Singhet al., 2009). Further, these herbicides are very effective for controlling weeds up to 20 DAT. Application of herbicide mixtures or sequential application of herbicides may be useful for broad-spectrum control of weeds in rice. Recent trend of herbicide use is to find out an alternative and effective weed management by using low dose high efficiency herbicides, which will not only reduce the total volume of herbicide per unit area, but also application becomes easier and economical to the farmer. Repeated use of same herbicide in the same field had often led to the occurrence of herbicide resistant weeds (Kim, 1996) and therefore, selection of herbicides with different mode of actions is also necessary for alternate application to avoid development of herbicide resistance in weeds. Herbicide 
mixtures may help prevent resistance problem as well as shift in weed population (Wrubel and Gressel, 1994). Proprietary mixture or tank mixture of different herbicides could often be preferred because they require less time, cost and increase the spectrum of weed control (Ooi et al., 2000). Application of herbicide mixtures or sequential application of herbicides may be useful for broadspectrum control of weeds in rice. Recent trend of herbicide use is to find out an alternative and effective weed management by using low dose high efficiency herbicides, which will not only reduce the total volume of herbicide per unit area, but also application becomes easier and economical to the farmer.

\section{Important weed species in transplanted rice}

A broad spectrum of weed flora infests rice crop. Diversified weed flora being noticed in paddy fields of different states (Table 1).

\section{Yield reduction by weeds in rice}

Weeds caused maximum yield reduction in direct seeded rice of dry seeded soil than puddle soil (Moody, 1977). Janiya (2002) stated that yield reduction by weeds was varied from 30-80 \% in direct seeded and 20$60 \%$ in transplanted rice. Kumar et al., (2013) critically analysed the impact of weeds on yield reduction and found that reduction in rice yield was $15.3 \mathrm{~kg} \mathrm{ha}^{-1}$ for increase in one weed per meter square and $32.5 \mathrm{~kg} \mathrm{ha}^{-1}$ reduction in grain yield for each gram increase in weed biomass. Uncontrolled growth of weeds during early stage (20-45 days after planting) led to reduction in yield was up to 25-53\% (Subbaiah and Sreedevi, 2000). Reddy et al., (2003) from Hyderabad noticed that Cyperus spp., Paspalum spp., Caesulia axillaris, Rotala densiflora and Monocharia vaginalis caused 28-40\% reduction in yield of transplanted rice.
Hossain et al., (2010) from Ranchi reported that the weed population as well as dry matter was reduced in transplanted rice with higher weed control efficiency resulting in higher grain yield.

\section{Crop-weed competition}

Weed competition is one of the major causes for yield loss in lowland rice in India. Weeds compete with the crop aggressively because of their high growth rate, high potential to acclimatize changing environment and more efficient seed production (Kim and Moody, 1989). Competition between crop and weed begins when the supply of any of the growth factor is limiting and falls below the demand of both crop and weeds, when they grow in close proximity. Weeds having faster growth rate, accumulate large amount of biomass in a short period, which interferes with the growth of rice plants and ultimately affects the yield of rice crop. Grasses are usually the most dominant competitors during early season, while sedges and broad-leaved weeds dominate later in the season (Jiang, 1989). Most of the reports also agreed that grasses are vigorous competitors, exhausting greater portion of the fertilizer applied to the crop followed by sedges and broad-leaved weeds (Singh et al., 2006). Similarly, sedges grow huge in number and cause serious competition for nutrients. The roots of the sedges also dominate the surface feeding zone and obstruct nutrient flow to crop roots. Generally, one-third duration of the crop period should be maintained weed free. The critical crop weed competition from 28-45 DAT in transplanted rice was reported by various workers (Singh et al., 2003). Singh et al., (2005) found that grasses constituted $14.1 \%$, sedges $71.4 \%$ and broad-leaf weeds $14.5 \%$ of the total weed population in rice crop at 30 days stage. Dhammu and Sandhu (2002) observed that Cyperus iria competition for the first 30 days caused less than one- 
fourth $(12.9 \%)$ of the total yield loss in transplanted rice while competition for 40 days resulted in more than half $(43.5 \%)$ of the total yield loss due to the weeds.

\section{Effect of crop-weed competition on rice}

Any weed growing in association with the crop will reduce vegetative potential of the crop and ultimately resulted in loss of yield (Moody, 1978). Many workers reported the effects of weed competition on rice growth and yield. Severe infestation of weeds suppressed the plant height (Bhargavi and Yellamanda Reddy, 1994) increased tiller mortality, decreased shoot and grain production (Srinivasan and Palaniappan, 1994). Singh et al., (2002) reported a reduction in grain yield in weedy check to the tune of $50.1 \%$. They also observed that maintaining weed free condition till maturity significantly reduced the density and dry weight of weeds and enhanced the grain yield due to a greater number of panicles $\mathrm{m}^{-2}$. Moorthy and Sanjoy Saha (2005) reported that losses in grain yield due to weed free condition upto 30, 60 and 90 DAT were 17.7, 11.8 and $5.0 \%$ respectively. The overall effect of crop weed competition is the reduction in the economic as well as biological yield of rice. In India, due to uncontrolled weed growth, yield of lowland rice was reduced by 17 to $73 \%$ (Choudhury and Thakuria, 1998). According to Tamil Selvan and Budhar (2001), weeds alone have been reported to reduce the yield by 50 to 60 $\%$ in direct sown rice.

\section{Effect of herbicides on weeds in rice field}

Herbicides effectively controlled the weed population. Dixit and Varshney (2008) conducted a field trail to evaluate the postemergence herbicides in direct seeded rice during the rainy season of 2001 and 2002 and reported that the post-emergence application of Pyrazosulfuron $25 \mathrm{~g} / \mathrm{ha}$ effectively controlled the infestation of Phyllanthus niruri, Alternanther asessilis, Commelina benghalensis, Physalis minima and Cyperusiria followed by one hand weeding. Incorporation of Dhaincha by spraying 2, 4-D resulted in $78 \%$ reduction in total weed count and $59 \%$ in weed dry matter production. Singh et al., (2004) observed that application of butachlor alone @ $1.25 \mathrm{~kg}$ a.i. ha ${ }^{-1}$ was effective against annual grasses. According to Rajkhowa and Gogoi (2004) application of butachlor@1.5 kg a.i. ha ${ }^{-1}$ as pre-emergence herbicide recorded significantly lower weed density and dry matter accumulation over weedy check. Hussain, et al., (2008)carried out a field experiment at Lahore, Pakistan. They found that bispyribacsodium proved the best weedicide with $90.5 \%$ weed control efficiency and paddy yield with 3.61 t/ha which was comparatively higher than other weedicides. Singh et al., (2005a) observed that bensulfuron methyl (Londax) at different doses (40 g a.i. ha ${ }^{-1}$ and $50 \mathrm{~g}$ a.i. ha ${ }^{-1}$ ) applied alone or as tank mixture with butachlor @ $1000 \mathrm{~g}$ a.i. $\mathrm{ha}^{-1}$ reduced the density of all the sedges and broad-leaved weeds and increased the grain yield. Ramana et al., (2008) reported that pre-emergence application of metsulfuron methyl + chlorimuron ethyl at $8 \mathrm{~g}$ a.i. ha ${ }^{-1}$ resulted in effective weed control as compared to other weed control treatments. Singh et al., (2008) reported that the density of sedges and broad-leaved weeds in almix treated plots were less as compared to application of butachlor, anilofos and pretilachlor alone.

Prakash et al., (2013) reported that the highest weed control was achieved with manual hand weeding (64-82\%). However, the hand weeding is laborious, tedious, expensive and time-consuming, hence it cannot be practicable on a large scale. Among the weedicides, bispyribac-sodium $50 \mathrm{~g} / \mathrm{ha}$ at $15-$ 20 DAT gave the highest weed control (58$75 \%$ ). Bispyribac-sodium at 25 and $35 \mathrm{~g} / \mathrm{ha}$ at 15-20 DAT reduced the weed density. The 
weed control efficiency with bispyribacsodium $50 \mathrm{~g} / \mathrm{ha}$ at $15-20 \mathrm{DAT}$ ranged between 58 and $75 \%$ The weed control efficiency with butachlor $1.5 \mathrm{~kg} / \mathrm{ha}$ at $5-7$ DAT ranged between 28 and $47 \%$, which was comparatively lower than other treatments.

\section{Effect of herbicides on nutrient uptake by rice}

Weeds usually grow faster than the crop plants and then they adsorb the available nutrients earlier, resulting in reduced availability to crop plants. Weeds being more vigorous competitors remove a greater portion of the fertilizer applied to the rice crop (Thirumurugan et al., 1998). Effective weed control measure increased the uptake of nutrients by the crop and decreased their removal by weeds. Finally, the weed free crop absorbs higher quantity of nutrient from the soil than weedy check. However, in chemical weeding systems, lower depletion was recorded at early stage when steadily increased towards later stages of crop growth. Because of their persistence in soil, it controls the weeds over an extended period of time. Devi and Singh (2018) reported that among weed management practices, application of bispyribac at $25 \mathrm{~g} / \mathrm{ha}+$ azimsulfuron at 17.5 $\mathrm{g} / \mathrm{ha}$ at $15-20$ DAS established their superiority in minimizing the nitrogen removable weeds which was significantly superior to other weed management treatments but it was next best to the hand weeding twice at 20 and 40 DAS.

\section{Effect of herbicides on growth and yield of rice}

Growth and yield also significantly influenced by herbicides. The higher grain yield was recorded with the pre-emergence application of butachlor followed by one hand weeding treatment and it was on par with butachlor followed by two hand weeding treatments
(Madhavi and Reddy, 2002). Application of butachlor@1.5 kg a.i. ha ${ }^{-1}$ as pre-emergence + 2, 4-D@0.5 kg ha ${ }^{-1}$ as post-emergence herbicide produced grain yield similar to hand weeding twice at 30 and 50 DAT (Singh et al., 2004). Among the herbicidal treatments, the lowest dry weight of weeds was recorded with butachlor @ $1.5 \mathrm{~kg}$ a.i. ha ${ }^{-1}+$ one handweeding, which was statistically similar to two hand weeding (Ramphoolpuniya et al., 2007). Application of butachlor at $1.25 \mathrm{~kg}$ a.i. $\mathrm{ha}^{-1}$ gave the efficient weed control and ultimately gave the maximum number of effective tillers ha $^{-1}$ (Mirza Hasanuzzaman et al., 2008).Among the herbicidal treatments, application of oxadiargyl @ $70 \mathrm{~g}$ a.i. ha ${ }^{-1}$ recorded higher number of panicles, 1000 grain weight and grain yield of rice (Kumar et al., 2004). Ramana et al., (2008) noticed that pre-emergence application of oxadiargyl at 80 g a.i. $\mathrm{ha}^{-1}+$ mechanical weeding with star weeder resulted in improved weed control and higher grain and straw yield and proved economically remunerative over butachlor and pretilachlor treatments. The highest number of filled grains panicle ${ }^{-1}, 1000$ grain weight and grain yield of rice were recorded with pre-emergence application of oxadiargyl @ $75 \mathrm{~g}$ a.i. ha ${ }^{-1}$, which was on par with hand weeding twice at 20 and 40 DAT (Yadav et al., 2009; Deepthi Kiran and Subramanyam, 2010). Application of almix @ $4 \mathrm{~g} \mathrm{ha}^{-1}$ mixed with butachlor@938 g ha ${ }^{-1}$ at 3 DAT was at par with hand weeding twice at 20 and 40 DAT in controlling weeds and achieving higher grain yield (Patra et al., 2006). Bensulfuron methyl at $60 \mathrm{~g}$ a.i. $\mathrm{ha}^{-1}$ tank mix with pretilachlor $450 \mathrm{~g}$ a.i. $\mathrm{ha}^{-1}$ applied at 20 DAS were found to be effective in controlling weeds with weed control efficiency of $92.2 \%$ and produced $5.53 \mathrm{t} \mathrm{ha}^{-1}$ of grain yield and this herbicide treatment was at par with hand weeding twice at 20 and 40 DAS (Sanjoy Saha and Rao, 2010). Singh et al., (2005b) reported that combination of pre-emergence application of pendimethalin @ $1.0 \mathrm{~kg}$ a.i. ha 
${ }^{1}$ and post emergence application of 2, 4-D @ $500 \mathrm{~g}$ a.i. ha $^{-1}$ recorded highest rice grain yield. Jacob and Syria (2005) noticed that post-emergence application of 2, 4-D Na salt @ $1.0 \mathrm{~kg}$ a.i. ha ${ }^{-1}$ at 20 DAT combined with pre-emergence application of anilofos @ 0.4 $\mathrm{kg}$ a.i. ha ${ }^{-1}$ generally favoured with increased yield.

Singh et al., (2018) reported that maximum grain yield $(5.05 \mathrm{t} / \mathrm{ha})$ was obtained under $\mathrm{T}_{11}$-weed free ( 2 hand weeding at 25 and 45 DAT), which was statistically at par with $(4.84 \mathrm{t} / \mathrm{ha} \mathrm{cm}) \mathrm{T}_{10}$-pendimithlin $750 \mathrm{~g} / \mathrm{ha}(0-3$ DAT) $f b$ bispyribac-sodium $25 \mathrm{~g} / \mathrm{ha} \quad(25$ DAT). This might be due to excellent performance of these treatments in terms of grain and straw yield due to better management practices and reduction in weed dry weight and its population (Table 2-4).

Table.1 Major weed flora of transplanted rice in different regions (Priyanka et al.2018)

\begin{tabular}{|c|c|c|}
\hline Major weed flora & Place & Reference \\
\hline Echinochloa crus-galli, Paspalum distichum and Caesulia axillaris & Pantnagar & Sarkar (2001) \\
\hline $\begin{array}{l}\text { Cyperus iria, Sphenoclea zeylanica, Leptochloa chinensis, Fimbristylis } \\
\text { miliacea and Eclipta alba }\end{array}$ & Karnal & Chopra andChopra(2003) \\
\hline $\begin{array}{l}\text { E.colona,E.crus-galli,Cyperusrotundus, Cyperusdifformis, Fimbristylis } \\
\text { miliacea, Ludwigia parviflora, and Ammania baccifera }\end{array}$ & Varanasi & MukherjeeandSingh(2004) \\
\hline E.crusgalli, Leersia hexandra, Marsilea quadrifolia & West Bengal & GhoshandGhosh (2005) \\
\hline $\begin{array}{l}\text { Echinochloa crusgalli,E.colona, } \\
\text { Cyperusiria,C.rotundus,Fimbristylismiliacea, Ammania baccifera, Marsilea } \\
\text { quadrifolia andPotamogeton distinctus }\end{array}$ & Kashmir & Singh et al.(2007) \\
\hline $\begin{array}{l}\text { Echinochloa glabrescens, E.colona(L.), Ammania baccifera (L), Euphorbia } \\
\text { spp., Fimbristylis miliacea (L.), Cyperus rotundus (L.), Cyperus iria (L.) } \\
\text { and Cyperus difformis (L.) }\end{array}$ & Karnal & Yadav et al.(2009) \\
\hline $\begin{array}{l}\text { Cyperus difformis, Fimbristylis miliacea, Scripus spp., C. procerus, } \\
\text { Echinochola colona, Panicum tripheron, Ludwigia parviflora, Spinanthus } \\
\text { acemella, Rotala verticillaris, Lindernia veronicaefolia andGlinus } \\
\text { oppositifolia }\end{array}$ & $\begin{array}{l}\text { Bangalore } \\
\text { Karnataka }\end{array}$ & $\begin{array}{r}\text { Ramchandra et } \\
\text { al.(2010) }\end{array}$ \\
\hline $\begin{array}{l}\text { Echinochloa crusgalli, Cynodon dactylon, Echinochloa colona, Cyperus } \\
\text { rotundus and Amaranthus viridis }\end{array}$ & Varanasi & SharmaandSingh(2010) \\
\hline $\begin{array}{l}\text { Digitaria sanguinalis, Echinochola crus-galli, E.colona, Panicum repens, } \\
\text { Fimbristylis miliacea, Cyperus rotundus, Cyperus iria, Cyperus difformis, } \\
\text { Ammania baccifera, Ludwigia parviflora, Eclipt prostrate, Eclipta alba, } \\
\text { Lippa nodiflora Nich, Marsilea quadrifolium, Sphenocleazeylanica, and } \\
\text { Commelina benghalensis }\end{array}$ & Orissa & Patra et al.(2011) \\
\hline $\begin{array}{l}\text { Cyperus rotundus, Cynodon dactylon, Echinochloa colonum, Ceasulia } \\
\text { axillaris, Phyllanthus niruri and Parthenium hysterophorus }\end{array}$ & Varanasi & Singh et al., (2014) \\
\hline $\begin{array}{l}\text { Echinochloa crusgalli, Echinochloa colonum, Leptochloa, } \\
\text { ChinensisCyperus difformis, Cyperus iria, Fimbristylis miliacea, Eclipta } \\
\text { alba, Ammania baccifera, Bergia capensis and Ludwigia parviflora }\end{array}$ & Tamil Nadu & ParthipanandRavi(2016) \\
\hline $\begin{array}{l}\text { Echinochloa sp., Panicum repens, Cynodon dactylon, Leptochloa chinensis, } \\
\text { Eclipta alba, Ludwigia parviflora and Cyperus sp. }\end{array}$ & $\begin{array}{l}\text { Raichur, } \\
\text { Karnataka }\end{array}$ & Ramesh et al., (2017) \\
\hline
\end{tabular}


Table.2 Effect of bispyribac-sodium on weed growth in transplanted rice

\begin{tabular}{|c|c|c|c|c|c|c|c|c|c|c|c|c|}
\hline \multirow[t]{2}{*}{ Treatment } & \multicolumn{2}{|c|}{$\begin{array}{l}\text { Weed density } \\
\left(\text { no. } / \mathbf{m}^{2}\right)\end{array}$} & \multicolumn{2}{|c|}{$\begin{array}{l}\text { Dry weight of } \\
\text { weeds }\left(\mathrm{g} / \mathrm{m}^{2}\right)\end{array}$} & \multicolumn{2}{|c|}{$\begin{array}{c}\text { Weed } \\
\text { persistence } \\
\text { index }\end{array}$} & \multicolumn{2}{|c|}{$\begin{array}{c}\text { Weed } \\
\text { competition } \\
\text { index }(\%)\end{array}$} & \multicolumn{2}{|c|}{$\begin{array}{l}\text { Weed control } \\
\text { efficiency }(\%)\end{array}$} & \multicolumn{2}{|c|}{$\begin{array}{l}\text { Herbicidal } \\
\text { efficiency } \\
\text { index }\end{array}$} \\
\hline & 2009 & 2010 & 2010 & 2010 & 2009 & 2010 & 2009 & 2010 & 2009 & 2010 & 2009 & 2010 \\
\hline Butachlor $1.5 \mathrm{~kg} / \mathrm{ha}$ at $5-7 \mathrm{DAT}$ & 24 & 22 & 32.7 & 35.8 & 0.18 & 0.14 & 13.6 & 16.4 & 28.2 & 47.7 & 0.80 & 0.97 \\
\hline Bispyribac-sodium $25 \mathrm{~g} / \mathrm{ha}$ at 15-20 DAT & 27 & 25 & 35.2 & 39.2 & 0.22 & 0.18 & 15.0 & 20.2 & 24.8 & 43.8 & 0.70 & 0.74 \\
\hline Bispyribac-sodium 35 g/ha at 15-20 DAT & 9 & 10 & 12.6 & 13.6 & 0.03 & 0.03 & 8.1 & 12.3 & 55.8 & 72.8 & 2.60 & 2.96 \\
\hline Bispyribac-sodium $50 \mathrm{~g} / \mathrm{ha}$ at 15-20 DAT & 7 & 8 & 10.4 & 11.0 & 0.02 & 0.02 & 5.7 & 11.5 & 58.7 & 75.7 & 3.39 & 4.02 \\
\hline Weed-free & - & - & - & - & & & - & - & - & - & & \\
\hline Two hand weedings ( 20 and 40 DAT) & 4 & 4 & 6.3 & 4.8 & 0.01 & 0.00 & 2.2 & 4.8 & 64.3 & 82.8 & & \\
\hline Unweeded control & 59 & 62 & 73.0 & 88.2 & 1.00 & 1.00 & 36.5 & 4.0 & & & & \\
\hline $\operatorname{LSD}(\mathbf{P}=0.05)$ & 2.13 & 2.10 & 2.13 & 3.14 & & & & & & & & \\
\hline
\end{tabular}

Table.3 Effect of different weed management treatments on grain yield (t/ha), straw yield (t/ha) and weed population of transplanted rice

\begin{tabular}{|l|c|c|c|}
\hline Treatments & $\begin{array}{c}\text { Grain } \\
\text { yield } \\
\text { (t/ha) }\end{array}$ & $\begin{array}{c}\text { Straw } \\
\text { yield } \\
(\mathbf{t} / \mathbf{h a})\end{array}$ & $\begin{array}{c}\text { Weed } \\
\text { population } \\
\text { at 90 DAT }\end{array}$ \\
\hline Bispyribac- Sodium & 4.01 & 4.88 & $18.44(4.35)$ \\
\hline Penoxsulam 24 \% SC & 4.05 & 4.93 & $18.94(4.41)$ \\
\hline Bispyribac - Sodium + Ethoxysulfuron & 4.68 & 5.71 & $10.81(3.36)$ \\
\hline Bispyribac - Sodium + Chlorimuron + Metsulfuron (Almix) & 4.31 & 5.53 & $12.33(3.38)$ \\
\hline Pretilachlor fb Ethoxysulfuron & 4.30 & 5.37 & $13.94(3.80)$ \\
\hline Pretilachlor fb Chlorimuron + Metsulfuron (Almix) & 4.37 & 5.62 & $13.58(3.75)$ \\
\hline Pyrazosulfuron fb Chlorimuron + Metsulfuron (Almix) & 4.35 & 5.49 & $14.74(3.90)$ \\
\hline Penoxsulam + Cyhalofop 6 \% OD & 4.27 & 5.17 & $17.35(4.22)$ \\
\hline Triafamone + Ethoxysulfuron 30 \% WG & 4.18 & 5.09 & $16.83(4.16)$ \\
\hline Pendimethalin (38.7 \% CS) fb Bispyribac -Sodium & 4.84 & 5.83 & $8.44(2.99)$ \\
\hline Hand weeding at 25 and 45 DAT & 5.05 & 6.35 & $5.11(2.37)$ \\
\hline Weedy check & 2.92 & 3.62 & $34.41(5.91)$ \\
\hline SEm \pm & 0.113 & 0.14 & 0.831 \\
\hline LSD (P=0.05) & 0.33 & 0.43 & 2.45 \\
\hline
\end{tabular}

Table.4 Yield performance of transplanted rice as influenced by different treatments

\begin{tabular}{|c|c|c|c|c|c|c|c|c|c|c|}
\hline \multirow[b]{2}{*}{ Treatment } & \multicolumn{2}{|c|}{$\begin{array}{c}\text { No. of } \\
\text { panicles /m2 }\end{array}$} & \multicolumn{2}{|c|}{$\begin{array}{c}\text { Panicle } \\
\text { weight (g) }\end{array}$} & \multicolumn{2}{|c|}{$\begin{array}{c}\text { Grain yield } \\
\text { (t/ha) }\end{array}$} & \multicolumn{2}{|c|}{$\begin{array}{c}\text { Straw yield } \\
(\mathbf{t} / \mathbf{h a})\end{array}$} & \multicolumn{2}{|c|}{$\begin{array}{c}\text { Harvest index } \\
(\%)\end{array}$} \\
\hline & 2009 & 2010 & 2009 & 2010 & 2009 & 2010 & 2009 & 2010 & 2009 & 2010 \\
\hline Butachlor $1.5 \mathrm{~kg} / \mathrm{ha}$ at $5-7 \mathrm{DAT}$ & 323 & 320 & 3.56 & 3.40 & 5.22 & 5.48 & 7.45 & 7.47 & 41.2 & 42.3 \\
\hline Bispyribac-sodium $25 \mathrm{~g} / \mathrm{ha}$ at $15-20$ DAT & 316 & 314 & 3.68 & 3.46 & 5. 14 & 5.23 & 7.24 & 7.05 & 41.5 & 42.6 \\
\hline Bispyribac-sodium $35 \mathrm{~g} / \mathrm{ha}$ at $15-20$ DAT & 345 & 347 & 3.95 & 3.90 & 5. 56 & 5.75 & 7.68 & 7.87 & 42.0 & 42.2 \\
\hline Bispyribac-sodium $50 \mathrm{~g} / \mathrm{ha}$ at $15-20 \mathrm{DAT}$ & 356 & 351 & 4.06 & 4.01 & 5.70 & 5.92 & 8.13 & 8.45 & 41.2 & 41.2 \\
\hline Weed-free & 382 & 385 & 4.41 & 4.32 & 6. 05 & 6.55 & 8.28 & 8.75 & 42.2 & 42.8 \\
\hline Two hand weedings ( 20 and 40 DAT) & 371 & 374 & 4.30 & 4.25 & 5.91 & 6.23 & 8.30 & 8.75 & 41.6 & 41.6 \\
\hline Unweeded control & 268 & 270 & 3.12 & 3.10 & 3. 84 & 3.94 & 5.76 & 5.41 & 40.0 & 42.1 \\
\hline $\operatorname{LSD}(P=0.05)$ & 15.0 & 13.5 & 0.18 & 0.21 & 0.20 & 0.23 & 3.60 & 3.90 & 2.3 & 2.3 \\
\hline
\end{tabular}


Prakash et al., (2013) reported that all the weed control treatments significantly reduced the weed growth as compared to weedy check, and thus recorded higher grain yield of rice. The crop yield andweed control efficiency were positively correlated. It was revealed that all the herbicides showed significant effects on grain yield. The highest rice yield was recorded from weed-free plot, followed by two hand weedings treatment. Among the herbicides, bispyribacsodium $50 \mathrm{~g} / \mathrm{ha}$ at 15-20 DAT resulted in the highest yield, which was at par with bispyribac-sodium $35 \mathrm{~g} / \mathrm{ha}$.

\section{Effect of herbicides on economics of rice}

Weed management should be practiced by least expensive available technology that does not interfere with other phases of crop production or human activities. Any weed control measure should be used only when its results are expected to be more economically beneficial then the results of not using any control measures (Moody, 1993). Chemical weed control always cost effective than other methods of weed controls this might be due to less cost involved in chemical treatment per unit of yield obtained. Pretilachlor and butachlor recorded good net return. Pretilachlor 625 $\mathrm{g} / \mathrm{ha}$ was reported more economical as compared to butachlor $1250 \mathrm{~g} / \mathrm{ha}$ getting good yield as well as cost benefit ratio (Sharma and Upadhyay, 2002). The highest net return $\left(15,990 \mathrm{ha}^{-1}\right)$ and $\mathrm{B}: \mathrm{C}$ ratio (2.00) was recorded in Metsulfuron methyl at $8 \mathrm{~g}$ ha $^{-1}$ (Sanjoy Saha and Rao, 2010). In transplanted rice, butachlor @ $1.0 \mathrm{~kg} \mathrm{ha}^{-1}$ on 3 DAT and almix @4.0 $\mathrm{g} \mathrm{ha}^{-1}$ on 20 DAT registered maximum monetary returns of 14,843 and $17,728 \mathrm{ha}^{-1}$ as well as $\mathrm{B}: \mathrm{C}$ ratio of 1.09 and 1.31 during 2006 and 2007 respectively (Mukherjee and Swapan Kumar Maity, 2011). Das., et al., (2017)concluded that the post-emergence application of bispyribac-sodium $25 \mathrm{~g} / \mathrm{ha}$ at $25 \mathrm{DAT}$ proved economical herbicide for transplanted rice as compared to hand weeding twice and also other herbicides and weedy check. The highest net returns of $25,340 \mathrm{ha}^{-1}$ and $\mathrm{B}: \mathrm{C}$ ratio of 3.15 was recorded with application of almix at $4 \mathrm{~g}$ a.i. $\mathrm{ha}^{-1}$ followed by one hand weeding on 30 DAT (Yoga Lakshmi, 2001). The highest B: $\mathrm{C}$ ratio of 2.47 was recorded with 2, 4-D Na salt at $1.5 \mathrm{~kg} \mathrm{ha}^{-1}$ applied at 10 DAS (Dani Tabin and Singh, 2008).

Hasanuzzaman et al., (2008) reported that the maximum net return was found with the treatment T6 (two hand weeding) which was almost similar with $T 2=$ Ronstar 25EC @ $1.25 \mathrm{Lh}^{-1}+$ IR587850WP@120 gha1 followed by $T_{1}=$ Amchlor $5 G @ 15 \mathrm{~kg} \mathrm{ha}^{-1}$ +IR587850WP@120 g ha ${ }^{-1}$, and $T_{5}=S e t-$ off 20WG@50g ha $a^{-1}+$ IR587850WP @ $120 \mathrm{~g} \mathrm{ha}^{-1}$. Net profit was highest from the treatment $\mathrm{T}_{2}$ (Ronstar 25EC @ $1.25 \mathrm{~L} \mathrm{ha}^{-1}+$ IR587850 WP @ $120 \mathrm{~g} \mathrm{ha}^{-1}$ ) which was even higher than $\mathrm{T}_{2}$ (two hand weeding). The application of $T_{2}$ maximized the profit and benefit-cost ratio (BCR) was the height (1.60) in the treatment. The second highest BCR (1.51) was obtained from the treatment $\mathrm{T}_{1}$. Glyphosate application at $0.75 \mathrm{~kg} \mathrm{ha}^{-1}$ on 15 days before transplanting of rice in combination with pre emergence application of bensulfuron methyl + pretilachlor at 5 DAT gave maximum profit in rice (Ramachandra et al., 2014). Similarly, Manisankar et al., (2019) found that pre plant application of glyphosate $2.5 \mathrm{~kg} \mathrm{ha}^{-1}$ registered higher net return and $\mathrm{B}: \mathrm{C}$ ratio of transplanted rice than control.

In conclusion the weeds are creating a major problem in rice production as they not only compete with crop but also hinder the quality of the rice produce. Control of weeds in rice crop is always a problematic task for effective crop production as their presence 
causes severe reduction in yield and quality of crop thus reducing yield productivity and profitability. Herbicide applications is commonly used to overcome weed infestation which is easy, quick, time saving, cost effective and it is most reliable method to control weeds. Rice crop is grown in diverse agro ecosystem therefore, weed communities and its types associated to rice are having a huge variation. Hence, the use of a single herbicide cannot give satisfactory and cost-effective results of weed control. Integrated strategies on chemical weed management is the best option to control the diverse weeds flora and the competitive ability of weeds for the above and below ground resources. Regular monitoring and early detection of the evolution and mechanism of herbicide resistance is necessary. The adoption of suitable management strategies on herbicide is utmost important. Hence, in the future, researchers need to develop different combinations of effective herbicides which do not only favour crop yield and reduce weed infestation but also discourage the resistance of weed flora to the herbicides.

\section{References}

Alstorm, S. 1990. Fundamental of Weed Management in Hot Climatic Peasant Agriculture. Swedish University of Agric. Sci., Uppsala, Sweden, pp. 5053.

Baloch, M.S. 1994. Evaluation of seeding densities and herbicide application for broad spectrum weed control indirect wet seeded rice. M.Sc. (Hons.) Thesis Gomal Uni. Dera Ismail Khan.

Bhargavi, K. and T. Yellamanda Reddy. 1994. Growth pattern of weeds and semi-dry rice (Oryza sativa) under various weed management practices. Indian J. Agron., 39(1): 113-116.

Chauhan, B.S. and Seth, A.B.2013. Weed Management in Mechanized-Sown,
Zero-Till Dry Seeded Rice. http.//dx.doi.org/10.1614/WT-D-120088.1.

Chopra, N.K. and Chopra, N. 2003. Effect of doses and stages of application of pyrazosulfuron-ethyl on weeds in transplanted rice. Indian J. of Weed Sci. 35: 27-29.

Choudhury, J.K. and R.K. Thakuria. 1998. Evaluation of herbicides in wet seeded, late Sali (winter) rice (Oryza sativa) in Assam. Indian J. Agron., 43 (2): 291294.

Dain Tabin and M.K. Singh. 2008. Effect of common salt and 2, 4-D Na salt application on weed growth andyield of upland direct seeded rice. Oryza, 45: 296-299.

Das R. 2017. Weed management in transplanted rice through bispyribacsodium $10 \%$ sc and its effect on soil microflora and succeeding crop blackgram". International Journal of Current Microbiology and Applied Sciences 4.6: 681-688.

Deepthi Kiran, Y. and D. Subramanyam. 2010. Performance of pre- and postemergence herbicides on weed flora and yield of transplanted rice (Oryza sativa). Indian J. Weed Sci., 42 (3\&4): 229- 331.

Devi BR and Singh Y. 2018. Effect of Nitrogen and Weed Management on Nutrient Removal by Weed in Direct Seeded Rice". International Journal of Current Microbiology and Applied Sciences 7.6: 1452-1459.

Dhammu, H. S. and Sandhu, K. S. 2002. Critical period of Cyperus iria $\mathrm{L}$. competition in transplanted rice. Proc. 13th Australian Weeds Conference: weeds "threats now and forever", Sheraton Perth Hotel, Perth, Western Australia, 8-13 September 2002: pp. 7982.

Dixit A and Varshney JG. 2008. Assessment of post emergence herbicides in direct seeded rice". Indian journal of Weed Science 40: 144-147.

Ferrero, A. and Tinarelli, A. 2007. Rice 
cultivation in the E.U. ecological conditions and agronomical practices. In: Pesticide Risk Assessment in Rice Paddies: Theory and Practice, (eds. Capri, E. \& Karpouzas, D.G.) Elsevier, ISBN: 978-0-444-53087-5, Amsterdam, pp. 124.

Ghosh, P. and Ghosh, R. K. 2005. Bioefficacy and phytotoxicity of clomazone $+2,4-\mathrm{D}$ for weed control in transplanted rice. Indian J. of Weed Sci. 37 (1\&2): 107-108.

Govindra Singh, V.P. Singh, Mahendra Singh and S.P. Singh. 2004. Effect of Fenoxaprop-p-ethyl on transplanted rice and associated weeds. Indian J. Weed Sci., 35: 119-120.

Hasanuzzaman M, Islam MO, Bapari MS (2008). Efficacy of different herbicides over manual weeding in controlling weeds in transplanted rice. Aust. J. Crop Sci., 2(1): 18-24.

Hossain, A., Duary, B. and Mondal, D. C. 2010. Effect of weed management under different methods of rice establishment in the lateritic soil of West Bengal. Biennial Conference on "Recent Advances in Weed Science Research2010”, Feb. 25-26, 2010, IGKV, Raipur (Chhattisgarh). pp. 63.

Jacob, D. and E.K. Syria. 2005. Performance of transplanted scented rice (Oryza sativa) under different spacing and weed management regimes in southern Kerala. J. Tropical Agri., 43 (1 -2): 7173.

Janiya, J. D. 2002. Weed management in major crops in the Philippines. Los Banos, Laguna, Philippines: In Weed Science Society of the Philippines. Yield losses, major weed species, and suggested management systems in selected major crops: rice, pp. 17-37.

Jiang, R.C. 1989. The field weeds chemical control series and systemic management. In: Proc. of the 1989 Asian Pacific Weed Sci. Conf., 467-473.

Khaliq, A.; Matloob, A.; Ahmad, N.; Rasul, F. and Awan, I.U. (2012). Post Emergence
Chemical Weed Control in Direct Seeded Fine Rice. The Journal of Animal \& Plant Sciences, 22(4): 2012, Page: 1101-1106.

Kim KU (1996). Ecological forces influencing weed competition and herbicide resistance. In: Herbicides in Asian Rice: Transitions in Weed Management (ed. Naylor R). Stamford University, California

Kim, S.C. and K. Moody. 1989. Growth dynamics of rice and several weed species under density and fertilizer stresses. In: Proc. of the 1989 Asian Pacific Weed Sci. Conf., 47-56.

Kumar, S., S. S. Rana and Chander, N. 2013. Mixed weed flora management by bispyribac-sodium in transplanted rice. Indian Journal of Weed Science. 45 (3): 151-155.

Kumar, V., A. Yadav and R.K. Malik. 2004. Effect of methods of rice transplanting and herbicides on Echinochloa crusgalli and rice. Indian J. Weed Sci., 36 (3\&4): 265-266.

Madhavi, M. and M.D. Reddy. 2002. Relative efficacy of herbicides on performance of wet seeded rice. Indian J. Weed Sci., 34 (1\&2): 128-130.

Main, A.L. and Al-Mamun, M.A. (1969). Chemical Control of Weeds in Transplant aman rice. The Nucleus. 6(3): 155-163.

Mandhata Singh and R.P. Singh. 2010. Efficacy of herbicides under different methods of direct-seeded rice establishments. Indian J. Agric. Sci., 80: 815-819.

Manisankar, G., T. Ramesh and Rathika, S. 2020. Weed Management in Transplanted Rice through PrePlant Application of Herbicides: A Review. Int.J.Curr.Microbiol.App.Sci. $9(05)$ : 684-692.

Mirza Hasanuzzaman, Md. Obaidulislam. Md. Shafiuddinbapari. 2008. Efficacy of different herbicides over manual weeding in controlling weeds in transplanted rice. Australian J. Crop 
Sci., 2 (1): 18- 24.

Moody, K. 1978. Crop-weed competition. Philippines J. Weed Sci., 5: 28-43.

Moody, K. 1993. Weed control in wet seeded rice. Experimental Agri. 29(4): 393-403.

Moody, K., 1977. Weed control in multiple cropping. Cropping Systems Research and Development for the Asian Rice Farmer. pp.281-293.

Mukherjee, D. and Singh, R. P. 2004. Efficacy of certain low doses herbicides in medium land transplanted rice. India $\mathrm{J}$. of Weed Sci. 36(1\&2): 47- 49.

Ooi KE, Amartalingam R, Omar D, Abd Halim MR (2000). Interactions of metsulfuron-methyl and glyphosate applied to foliage of woody borreria (Diodiaocimifolia). Proceedings of the 17 the Asian-Pacific Weed Science Society Conference Bangkok, Thailand, pp. 389-394.

Parthipan, T. and Ravi, P. 2016. Productivity of transplanted rice as influenced by weed control methods. African J. of Agri. Res. 11(16):1445-1449.

Patra, A.K., Halder, J., and Mishra, M.M. 2011. Chemical weed control in transplanted rice in Hirakud command area of Orissa. Indian J. of Weed Sci. 43(3\&4): 175-177.

Patra, A.K., J. Haldar and S.K. Tripathy. 2006. Chemical weed control in transplanted rice in Hirakud Command Area. Ann. Agric. Res. New Series, 27: 385-388.

Prakash, C., R. K. Shivran and Koli, N. R. 2013. Bioefficacy of new herbicides in transplanted rice. Indian Journal of Weed Science. 45 (4): 282-284.

Priyanka Kabdal, Tej Pratap and Vimal Raj Yadav. 2018. Weed Management in Transplanted Rice-A Review. Int.J.Curr.Microbiol.App.Sci. $\quad$ 7(04): 1660-1669.

Ramachandra, C., N. Shivakumar and Ningaraju, G. K. 2014. Effect of herbicides and their combination on weed dynamics in rice-based cropping system. Indian Journal of Weed Science. 46 (2): 123-125.
Ramana, A.V., G.S. Naidu and M. Bharatha Lakshmi. 2008. Effect of some new herbicides in rainfed upland rice (Oryza sativa). The Andhra Agric. J., 55 (2): 141- 143.

Ramchandra, C., Denesh, G.R. and Sydanwarulla. 2010. Weed management practices in transplanted rice by using glyphosate. Biennial Conference on "Recent Advances in Weed Science Research-2010", February 25-26, 2010, Indira Gandhi Krishi Vishwavidyalaya, Raipur (Chhatisgarh). pp. 68.

Ramesha, Y.M., Bhanuvally, M., Gaddi, A.K., Krishamurthy, D. and Umesh, M.R. 2017. Efficacy of herbicides against weeds in transplanted Rice (Oryza sativa L.). Int. J. of Plant and Soil sci. 18(1): 1-8.

Ramphoolpuniya, P.C., Bishot and D.K. Singh. 2007. Nutrient update by crop and weeds as influenced by Trisulfuran, Trisulfuran + pretilachlor and Bensulfuran methyl in transplanted rice (Oryza sativa L.). Indian J. Weed Sci., 39 (3\&4): 239- 240.

Reddy, C.N., Reddy, M.D. and Devi, M.P. 2003. Effect of cinosulfuron on weeds and transplanted kharif rice. Indian J. of Weed Sci. 35(1\&2): 117-118.

Sanjoy Saha and K.S. Rao. 2010. Evaluation of bensulfuron methyl for weed control in wet direct-sown summer rice. Oryza, 47 (1): 38-41.

Sarkar, N.C. 2001. Studies on chemical weed control in transplanted rice (Oryza sativa). M.Sc. Ag. (Agronomy) Thesis G.B. Pant University of Agriculture and Technology, Pantnagar. pp: 108-112.

Sharma, R. and Upadhyaya, V. B. 2002. Bioefficacy of acetachlor in transplanted rice. Indian J. of Weed Sci. 34 (3\&4): 184- 186.

Subbaiah, S. V., and Sreedevi, B. 2000. Efficacy of Herbicide Mixtures on Weed Control in Direct Seeded Rice under Puddled Condition. Indian Journal of Weed Science. 32 (3\&4): 199-200. 
Singh, G.P., Roy, D.K. and Yadav, S. 2018. Effect of herbicides combinations and hand weeding on growth, yield and weed population in transplanted rice (Oryza sativaL.). International Journal of Chemical Studies 6(5): 154-157.

Sharma, S.N. and Singh, R.K. 2010.Weed management in rice wheat cropping system under conservation tillage. Indian J. Weed Sci. 42(1\&2): 23-29.

Singh VP, Singh SP, Tripathi N, Singh MK, Kumar A. Bioefficacy of penoxsulam on transplanted rice weeds. Indian journal of weed Science. 2009; 41(1\&2):28-32.

Singh, A.K., Singh, M.K., Prasad, S.K. and Sakarwar, P. 2014. Sequential herbicide application and nitrogen rates effect on weeds in direct seeded rice (Oryza sativa L.). The Ecoscan 8(3\&4):249252.

Singh, D.K. and A.N. Tewari. 2005. Effect of herbicides in relation to varying water regimes in controlling weeds in direct seeded puddled rice. Indian J. Weed Sci., 37: 193-196.

Singh, G., Singh, V. P., Singh, M. and Singh, S.P. 2003. Effect of anilofos and triclopyr on grassy and non-grassy weeds in transplanted rice. Indian J. of Weed Sci. 35 (1\&2): 30-32.

Singh, P., Singh, P., Singh, R. and Singh, K.N. 2007. Efficacy of new herbicides in transplanted rice (Oryza sativa) under temperate conditions of Kashmir. Indian J. of Weed Sci. 3(3 \&4): 167-171.

Singh, R.K., S.N. Sharma, R. Singh and M.D. Pandey. 2002. Efficacy of method of planting and weed control measures on

\section{How to cite this article:}

Shipra Yadav, R. B. Yadav, Sanjay Singh Chuhan, Rahul Kumar and Virendra Kumar. 2020. Efficacy of Different Herbicides and its Combination against the Weed Flora of Transplanted Rice: A Review. Int.J.Curr.Microbiol.App.Sci. 9(08): 2057-2068.

doi: https://doi.org/10.20546/ijcmas.2020.908.233 nutrient removal of rice (Oryza sativa L.) and associated weeds. Crop Res., 24 (3): 425-429.

Singh, U.P., R.K. Singh and R.P. Singh. 2004. Performance of herbicides and cultivars under zero till situation of rainfed lowland rice eco-system. Indian J. Weed Sci., 36 (1\&2): 122-123.

Singh, V.P., R.P. Singh and V. Singh. 2006. Integrated weed management in direct seeded rainfed low land rice. Indian J. Weed Sci., 38 (1\&2): 49-53.

Srinivasan, G. and S.P. Palaniappan. 1994. Effect of major weed species on growth and yield of rice (Oryza sativa). Indian J. Agron., 39 (1): 12-15.

Thirumurugan, V., R. Balasubramanian. and T. Thanasekaran. 1998. Influence of field preparation, planting methods and weed management on rice. Pestology, 22 (1): 11-16.

Wrubel R P, Gressel J (1994). Are herbicide mixtures useful for delaying the rapid evolution of resistance? A case study. Weed Technol., 8: 635-48.and IRRI, Philippines, pp. 129-142.

Yadav, D. B., Yadav, A. and Punia, S. S. 2009. Evaluation of Bispyribac-sodium for weed control in transplanted rice. Indian J. of Weed Sci. 41(1\&2): 23-27.

Yadav, D. B., Yadav, A. and Punia, S. S. 2009. Evaluation of Bispyribac-sodium for weed control in transplanted rice. Indian J. of Weed Sci. 41(1\&2): 23-27.

Yogalakshmi, K. 2001. Evaluation of the herbicide Almix + Machete tank mix in transplanted rice crop. M.Sc.(Ag.), Thesis, TNAU, AC\&RI, Madurai. 